\title{
DETECCIÓN DE RODEOS LECHEROS CON HIDATIDOSIS A PARTIR DE INFORMACIÓN PROVENIENTE DE FRIGORÍFICO
}

\author{
Abdala, A. A. ${ }^{1} \&$ TARABLA, H. D. ${ }^{1,2}$
}

\begin{abstract}
RESUMEN
Echinoccocus granulosus es el agente causal de hidatitosis más importante en la Argentina. Las zonas más afectadas se encuentran en estrecha relación con la ganadería ovina-caprina, existiendo pocos antecedentes en áreas de ganadería bovina intensiva. A partir de información obtenida en frigorífico, se estimó la infección hidatídica en rodeos y vacas lecheras en la cuenca lechera de la provincia de Santa Fe, Argentina. Las observaciones se realizaron en un frigorífico local, inspeccionándose 4.200 vacas pertenecientes a 743 rodeos. Se observaron lesiones en el 6,5\% de los animales y el $25,5 \%$ de los rodeos. Estas prevalencias variaron por distritos. Los órganos más afectados fueron los pulmones $(70,5 \%)$ y el hígado $(25,6 \%)$. La prevalencia de vacas positivas fue semejante a la nacional $(6,2 \%)$. La escasa población ovina existente en el área, sugiere que el ciclo de la enfermedad debería ser sostenido por otros hospedadores intermediarios como bovinos y cerdos.
\end{abstract}

Palabras claves: hidatidosis, ganado lechero.

\section{SUMMARY}

\section{Detection of dairy herds with hydatidic disease by using abattoir data.}

Echinoccocus granulosus is the most important causative agent of hydatidic disease in Argentina. The most affected areas are in close relationship with sheep-goat production, but there are very few reports on areas of intensive cattle production. The objectives of this study were to identify herds with hydatidosis in the central area of Santa Fe, Argentina and estimate the prevalence of the disease based on abattoir data. Observations were carried out on 4,200 Holstein cows ( 743 herds) sent to slaughter to a local abattoir in three consecutive years. Disease was present on $6.5 \%$ of the cows and $25.5 \%$ of the herds. These prevalences varied according to the area of origin. The most affected organs were lungs $(70.5 \%)$ and liver $(25.6 \%)$. The small sheep population present on this area suggests that the parasite cycle must be sustained by alternative intermediate hosts, like cattle and pigs.

Key words: hydatidic disease, dairy cattle.

1.- INTA, EEA Rafaela. C. C. 22. (2300) Rafaela, provincia de Santa Fe. Email: aabdala@rafaela.inta.gov.ar 2.- Facultad de Ciencias Veterinarias, Universidad Nacional del Litoral. Kreder 2805. Esperanza, provincia de Santa Fe.

Manuscrito recibido el 31 de agosto de 2009 y aceptado para su publicación el 6 de noviembre de 2009. 